Macmillan
Work Out

Series

\title{
Work Out
}

\section{French}

\section{'A' Level}




\section{The titles \\ in this \\ series}

For examinations at $\mathbf{1 6}+$

Accounting

Human Biology

Biology

Mathematics

Chemistry

Computer Studies

Numeracy

Economics

Physics

English

Social and Economic History

Sociology

French

Spanish

German

Statistics

Graphic Communication

World History

For examinations at ' $A$ ' Level

Accounting

Applied Mathematics

English Literature

French

Physics

Biology

Pure Mathematics

Chemistry

Statistics

For examinations at college level

Dynamics

Mathematics for Economists

Electromagnetic Fields

Operational Research

Electronics

Organic Chemistry

Elements of Banking

Physical Chemistry

Engineering Thermodynamics

Fluid Mechanics

Waves and Optics 


\section{MACMILLAN WORK OUT SERIES}

\section{Work Out}

\section{French}

\section{'A' Level}

\section{Maun}

Editorial Consultant

BetTy PARR

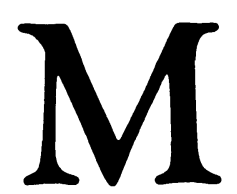

MACMILLAN 
๑) I. C. Maun 1989

All rights reserved. No reproduction, copy or transmission of this publication may be made without written permission.

No paragraph of this publication may be reproduced, copied or transmitted save with written permission or in accordance with the provisions of the Copyright Act 1956 (as amended), or under the terms of any licence permitting limited copying issued by the Copyright Licensing Agency, 33-4 Alfred Place, London WC1E 7DP.

Any person who does any unauthorised act in relation to this publication may be liable to criminal prosecution and civil claims for damages.

First published 1989

Published by

MACMILLAN EDUCATION LTD

Houndmills, Basingstoke, Hampshire RG21 2XS

and London

Companies and representatives

throughout the world 


\section{Contents}

Series Editor's Preface

viii

Author's Preface

ix

How to Use this Book

Acknowledgements

Organisations Responsible for Examinations at 'A' Level and 'AS' Level

xii

xii

\section{PART I TEACHING UNITS}

$1 \quad$ Paris

1.1 Le Centre Pompidou: Beau ou Laid?

Victor Vasarely

1.2 Un Amateur de Paris

L. A. Prévost-Paradol

1.3 Conversation

1.4 Promenade Poétique Louis Aragon

1.5 Further Reading

2 Une Région - La Bretagne

2.1 Une Vision

$$
\text { Anatole Le Braz }
$$

2.2 L'Avenir et la Culture H. Krier et L. Ergan $\quad 20$

2.3 Conversation 25

2.4 Promenade Poétique $\begin{array}{ll}\text { J.-M. de Heredia } & 27\end{array}$

2.5 Further Reading $\quad 27$

3 L'Environnement $\quad 28$

3.1 Le Peuple des Campagnes - J. Vidalenc 28

3.2 Un Nouveau Dragon - Brigitte Friang 31

$\begin{array}{lll}3.3 \text { Conversation } & 35 \\ 3.4 & 35\end{array}$

$\begin{array}{ll}3.4 & \text { Promenade Poétique - Jacques Maillart } \\ 3.5 & 37\end{array}$

$\begin{array}{lll}3.5 & \text { Further Reading } & 37\end{array}$

$4 \quad$ Une Société Qui Evolue $\quad 38$

4.1 L'Industrie Depuis $1945-C$. Stoffaes 38

4.2 Le Fléau du Chômage - Gérard Mermet 42

4.3 La Crise du Logement - Alain Kimmel 45 
4.4 Conversation $\quad 50$

4.5 Promenade Poétique - Paul Verlaine 52

4.6 Further Reading 52

$5 \quad$ L'Enfance

5.1 Une Jeune Fille Rangée - Simone de Beauvoir

5.2 Une Enfance Provençale - Marcel Pagnol 57

5.3 Conversation 61

5.4 Promenade Poétique - Victor Hugo 62

5.5 Further Reading 63

6 L'Adolescence

6.1 Une Adolescence de Génie - Eve Curie

6.2 Une Adolescence d'Avant-Guerre - Robert Sabatier

6.3 Une Leçon de Conduite - Christiane Rochefort

6.4 Conversation

6.5 Promenade Poétique - Jacques Prévert

6.6 Further Reading

$7 \quad$ L'Education

7.1 La Raison - Pour ou Contre? - J.-J. Rousseau

7.2 Rebrousser Chemin - Sophie Latil

7.3 En Classe On Se Laisse Aller - Maurice T. Maschino

7.4 Conversation

7.5 Promenade Poétique - Claude Roy

7.6 Lecture Supplémentaire

8 La Communication

8.1 Le Français Tel Qu'on le Parle - Henri Mitterand

8.2 Un Cinéaste Extraordinaire - Jean Renoir

8.3 Conversation

8.4 Promenade Poétique - Paul Verlaine

8.5 Lecture Supplémentaire

9 La Condition Féminine

9.1 L'Ecole des Femmes - Molière

9.2 Nature ou Culture? - M.-J. et P. H. De Lauwe

9.3 Les Femmes Travailleuses - Pascal Lainé

9.4 Conversation

9.5 Promenade Poétique - Charles Baudelaire

9.6 Lecture Supplémentaire

10 La Violence

10.2 La Psychose de la Violence - Minelle Verdié

10.3 Conversation

10.4 Promenade Poétique - Arthur Rimbaud

10.5 Lecture Supplémentaire

11.2 La Technique du Conte: La Parure de Guy de Maupassant

11.3 Approfondir un Thème: L'Honneur dans Becket par Jean Anouilh 


\section{PART II REFERENCE SECTION}

1. Key to Questions and Exercises $\quad 149$

2. Grammar Summary $\quad 179$

$\begin{array}{ll}\text { Table of Contents } & 179\end{array}$

Index to Grammar Summary 232

3. Guide to Pronunciation 241

PART III THE 'A' LEVEL EXAMINATIONS

$\begin{array}{ll}\text { Aims } & 251 \\ \text { The Examinations } & 251 \\ \text { Schemes of Examination } & 254 \\ \text { Sample Material } & 254\end{array}$

$\begin{array}{ll}\text { Bibliography and Sources of Information } & 265\end{array}$ 


\section{Series Editor's Preface}

This course is intended for students who wish to extend still further their command of spoken and written French, and to deepen their understanding of France and the French people. The book and its accompanying cassette, which can be used with or without a teacher, should prove valuable to those seeking to attain a standard similar to that required for a good grade in the ' $A$ ' Level examination*. Students without an examination in view should also benefit from this stimulating and well-co-ordinated programme of study for advanced work.

The course has certain distinctive features. The basic teaching material, which consists of carefully chosen texts from contemporary sources as well as from established writers from the seventeenth century to the present day, relates to a range of topics on various aspects of French life and thought. Each extract is followed by ingenious and progressive exercises, planned to develop in the student an understanding and mastery of the French language, as well as an appreciation of its special qualities. In the first six chapters, the explanations and instructions are in English, but thereafter all the material is in French, so that a sense of style may be developed naturally, through consistent use. Each chapter includes a recorded discussion on the main topic under review, so that the differences between educated speech and good writing may be studied at first hand. Though the reading material is inevitably limited by the space available, the student is encouraged to read more widely by the inclusion of a programme of supplementary reading, which amplifies and enriches the themes of the chosen texts.

The Reference Section contains a key to the exercises, to help students to work independently and assess their own progress. In the substantial grammar summary, reference is made to the selected texts, in which relevant passages exemplify the item in question. Other useful material, including a section on developments in the ' $A$ ' Level examination, is mentioned in the Author's Preface, which gives invaluable advice on ways of using the course effectively.

It is hoped that this stimulating book may bring to the thoughtful student a growing mastery of the French language and a deeper understanding of France and her people.

Yeovil, 1989

Betty Parr

\footnotetext{
* An earlier publication - Work Out French GCSE, by E. J. Neather - was devised for students with more modest linguistic equipment and objectives (1986, Macmillan). Mastering French 2 - France and the French - also by E. J. Neather (Macmillan Education, 1985), would provide an admirable bridge between Work Out French GCSE and this course.
} 


\section{Author's Preface}

The Series Editor's Preface has already indicated that this Course is intended for students, with a good command of spoken and written French, who now wish to develop their proficiency, either with a view to attempting the 'A' or 'AS' Level examination, or for the simple pleasure of learning more French and becoming better acquainted with France and her people.

The Course aims to provide a sound understanding not only of the grammar required for a more advanced level of French study, but also of the differences between the written and spoken language, and the rich variety of styles in French. It is often assumed that the learning of an amorphous mass called 'French' will equip the student to understand, speak and write it in most situations. Even a superficial study of a variety of texts and recordings in different registers will expose this fallacy, and show that a much broader conception of the language is needed. Within the limited scope of this book, a serious attempt is made to show something of the rich variety of the French language and its development from the seventeenth century to its contemporary mode, which reflects some of the complexities of present-day life while still maintaining its essential clarity.

The title of the book indicates the level of linguistic study involved, but it will be obvious that no attempt is made - even if it were feasible - to 'prepare' the student for a specific 'A' Level examination syllabus. The demands of the Boards vary considerably and the very nature of the examination is in the process of change, as will be seen in Part III of this book. It can be said, however, that this Course does contain a good range of the type of test set at 'A' Level, as well as a variety of exercises designed to develop all the language skills.

\section{How to Use this Course}

As the table of contents indicates, each chapter deals with a topic which is presented in two or three selected texts, followed by a recorded conversation on the theme. A general introduction and explanatory notes, together with varied exercises, are devised to help the student to understand the language and to use it in different ways. No vocabulary list is provided, for the intelligent use of a dictionary is essential at this stage (see Bibliography for suggestions).

With chapters dealing with contemporary issues such as nuclear power and unemployment, it may be helpful to read about the same subject in English, before tackling the French text. This preparatory work may well help to provide the meaning of newly encountered words or suggest possible translations of key phrases.

Each text is followed by a set of comprehension questions. In the first six chapters, these questions and all explanations are in English. From Chapter 7 
onwards, all questions and explanations are in French, the only English being an occasional translation exercise. If the text has provided difficulties, the comprehension questions themselves may help to solve these by suggesting a point on which to focus. The answers to the comprehension sections, as well as to all other exercises, are to be found in the Key in Part II.

The exercises on each text are divided into two sections.

Section A is concerned with vocabulary and style, and has a number of short exercises. A commentary draws attention to features of interest, both linguistic and cultural, and attempts to show differences of style and register, and to point out problems of translation. It is recommended that a dictionary be used to assist in checking possible answers, before the student refers to the Key.

Section B is concerned with grammar, and an introduction to the section lists the points on which the exercises are based, and indicates the relevant items in the grammar reference section at the end of the book. Before consulting the grammar summary, the student may like to look at the example given at the head of each exercise and deduce how this particular piece of language works. Having made the deduction, or checked the grammar, the student should then attempt the exercise. Some exercises require the use of the accompanying cassette, and for others it is recommended that the students practise saying their answers aloud. Indeed, for all the exercises, no harm will be done if students practise saying their answers or recording them on a cassette, although some constructions practised will tend to occur more in the written than the spoken language.

It is not expected that candidates at 'A' Level will be able to use actively all the constructions that occur in the exercises in this book, but it is certain that practice with them will be a valuable preparation for any possible encounter in an 'A' Level text. Having done the exercises, the student should check the answers in the Key, and if there are any mistakes, the text, the grammar and the exercise should obviously be revised.

A detailed Index is provided at the end of the grammar section. This lists the text in which particular words and grammatical points occur, and the section of the Grammar Summary giving a detailed explanation. For example, the Index lists dont which appears also under Relative pronoun.

After the grammatical exercises, the majority of the texts have an assignment. This exercise is designed to help the student to manipulate the language in more continuous prose. Various types of exercise are included, including précis and dialogue-writing. Other assignments will involve the use of information in the text to answer questions or to refute or support arguments. An orderly approach is essential, as these exercises will help in the writing of essays and presentation of arguments, in which both content and exposition are important at this level. Each student will, of course, produce a different answer to the assignment, but a suggested response will be found in the Key, and this will form a useful basis of comparison. It is advisable to note any useful words and expressions from the suggested answer, as well as any tricks of argument.

At the end of each chapter, there is a recorded conversation, the text of which will be found on the accompanying cassette. The exercise which precedes the printed transcript should be read through before listening to the cassette or reading the transcript. The cassette should be played through as many times as is necessary, before answering the questions or preparing a summary as required. The transcript will help to fill any gaps, and the answers should then be checked against those in the Key. It will certainly be useful to go through the transcript with the aid of a dictionary.

Following the conversation, there is a section entitled Promenade Poétique. This contains a poem, related as closely as possible to the theme of the chapter. There are, however, no exercises associated with the poem, which has been 
included purely for the reader's pleasure.

Finally, a short section suggests books and magazines which students might wish to read to enlarge their knowledge and understanding of the themes of the chapters. Some will be more easily obtainable than others. If a university library is accessible, much help could be found there. Addresses of some bookshops dealing in French books are listed in the Bibliography.

Chapter 11 deals with three works of literature, and shows how different aspects of a work may be approached. Each section takes the form of a critical essay, which also explains some of the characteristics of a work of literature and ways in which an author achieves his effects. The works discussed here may not be the set texts for one particular Board, but the general principles hold true for any book.

A selection of ' $A$ ' Level questions is to be found in Part III. These have been chosen to tie up as closely as possible with the topics discussed in this book. Such a choice of themes is, however, in the final analysis, fairly arbitrary, and students should be aware of the variety of topics dealt with at 'A' Level. Past examination papers are available from the Examination Boards, whose addresses are listed in the preliminary pages.

To study a language out of a book is a second-best measure, and students must be aware that it is vital to have first-hand experience of speaking French with native speakers. It is virtually essential for the student to visit France and to absorb as much as possible of the language through speaking to people, reading, listening to the radio and watching television, writing letters and visiting sites of cultural interest. Learning a language is not easy, but I hope that this Course will bring pleasure to the difficult but rewarding task of mastering French.

Teignmouth, 1989

I. C. M. 


\section{Acknowledgements}

This book is dedicated to Ted Neather in grateful acknowledgement for all that he has done for the author over the last few years.

The author wishes to thank all those who assisted in the preparation of this book, in particular André Stervinou, Bernard Cabon and Marc and Catherine Regnault, who recorded the original interviews.

The author and publishers wish to thank the following Examination Boards for permission to reproduce specimen examination questions:

The Associated Examining Board

The Joint Matriculation Board

The Oxford and Cambridge Schools Examination Board

The University of Oxford Delegacy of Local Examinations

The University of London School Examinations Board

The author and publishers wish to acknowledge the following photograph and drawing sources:

Vidocq Photo Library, Frome (particularly for the cover illustration)

André Laubier, Bath

Camera Press Ltd, London

BBC Hulton Picture Library

The National Film Archive

The Mansell Collection, London

Ram Ahronov

The author and publishers would also like to thank R. E. Batchelor and M. H. Offord for their kind permission to quote from A Guide to Contemporary French Usage (Cambridge University Press).

Every effort has been made to trace all the copyright holders but if any has been inadvertently overlooked the publishers will be pleased to make the necessary arrangements at the first opportunity.

\section{Organisations Responsible for Examinations at 'A' Level and ' $A S$ ' Level}

In the United Kingdom, 'A' Level and 'AS' Level examinations are administered by the following organisations (syllabuses and examination papers can be ordered from the addresses given here):

The Associated Examining Board (AEB)

Stag Hill House

Guildford

Surrey GU2 5XJ
University of Cambridge Local Examinations Syndicate (UCLES) Syndicate Buildings

1 Hills Road

Cambridge CB1 2EU 
University of Oxford

Delegacy of Local Examinations

(OLE)

Ewert House

Ewert Place

Summertown

Oxford OX2 7BZ

Southern Universities' Joint Board

Cotham Road

Bristol BS6 6DD

University of London School

Examinations Board

Stewart House

32 Russell Square

London WC1B 5DN

Northern Ireland Schools

Examinations Council

Examinations Office

Beechill House

Beechill Road

Belfast BT8 4RS
Oxford and Cambridge Schools

Examination Board (O \& C)

Elsfield Way

Oxford OX2 8EP

Joint Matriculation Board (JMB)

Manchester M15 6EU

Publications available from:

John Sherratt \& Son Ltd

78 Park Road

Altrincham

Cheshire WA14 5QQ

Welsh Joint Education Committee 245 Western Avenue

Cardiff CF5 2YX 